\title{
Possibilities of Electrical Power Production by Incineration Process: A review
}

\author{
Mr. Kaushal K. Bhatt ${ }^{1}$, Mr. Jayrajsinh B. Solanki ${ }^{2}$ \\ Assistant Professor, Electrical Department, Govt. Engineering College, Sector-28, Gandhinagar, Gujarat, India ${ }^{1}$ \\ Assistant Professor, Electrical Department, B. \& B. Institute of Technology, Vallabhvidyanagar, Gujarat, India ${ }^{2}$
}

\begin{abstract}
This review paper gives insight of an incineration process of solid waste management system. By this method if handled with proper design gives enough energy for electrical power production. This review paper shows how power can be generated by this method like a power plant sized dependent upon the mass of solid waste available from a particular area in which it is to be installed. This paper also shows the possibilities of electrical power production at various area dependent upon the solid waste available. A list of energy available from various solid wastes material is also included in this paper. Finally advantages and disadvantages of Incineration process is given in conclusion.
\end{abstract}

Keywords: Solid waste management, incineration, electric power production, energy from Waste, MSW, Waste to energy.

\section{INTRODUCTION TO INCINERATION PROCESS}

Incineration is the converting energy from waste by petrochemical type waste is such origins. Examples of controlled burning. Burning process converts solid as well Biological waste are food waste, timber, animal fats and as liquid and gasses into ash and a huge amount of exhaust Paper. The Examples of petrochemical waste are solvents gases. Outlet gases are followed by cleaning procedure and plastics.

before getting released in normal air at outlet to incineration plant. As per the type of the waste ash is used either in bricks manufacture construction or in sent preparation for landfill. After the incinerators process the heat produced is recovered in the form of hot gases and used to generate electrical power to prepare steam. Due to this, incinerators procedure is often known as Energy from Waste (EfW) or Waste to Energy (W2E) procedure [1]. Incineration procedure is known as thermal treatment also. Incineration can be used for a number of waste types like [1]

1. Municipal solid waste (MSW)

2. Domestic rubbish,

3. Industrial and chemical wastes,

4. Contaminated material from health care

5. Residues from animal processing.

Incinerators power plant size depends upon the mass of MSW available. It may run form a small unit like a single industries or it may run from MSW available from a city as well.

\section{COMBUSTION}

To get heat from MSW it has to be reacted with oxygen andget broken down into composite molecules so as the heatgets released. For combustion to happen three things are needed 1)supply of oxygen 2) fuel, and 3) high temperature are needed.

A. Fuel:

All materials cannot burn itself they need burning agents to get reaction of combustion process. Waste which is made of organic material which have carbon components are main fuel components. Biological type waste and

B. Oxygen:

Simpler oxide molecules in Combustion process is created once oxygen combines with the fuel in the chemical process of burning of MSW. When a fuel having carbon chemically does reaction with oxygen the carbon dioxide $(\mathrm{CO} 2)$ is formed and heat is released. To burn properly there should beadequate amount of oxygen to do chemical reaction with the fuel. Where oxygen comes in total direct contact with the fuel the reaction can only occur. Solid material have such reaction at surface only so that they have to Brocken in to small particles or pallets to have total burning of the fuel.

C. Temperature:

At high temperature only the reaction with oxygen occurs in a good manner. The temperature needed depends upon the material and can be as high as $800 \mathrm{oC}$. The moisture in MSW is first boiled off as the fuel heats up. After that released volatile gases mixes with oxygen in the air to have chemical reaction of burning. Solid carbon burns thereafter.

D. Combustion By-Products

After a Complete combustion of fuel following out puts will be available [1].

1. Carbon is converted to carbon dioxide $(\mathrm{CO} 2)$,

2. Hydrogen is converted to water $(\mathrm{H} 2 \mathrm{O})$,

3. Sulphur is converted to sulphur dioxide (SO2)

4. Nitrogen is converted into nitrous oxides (NOx).

All of these will be released at the output of the incineration process. Solid residue or ash is produced when some of the parts of MSW is containing other parts as such metals. Dependent on the fuel consumption percentage the amount of ash varies and is mostly less 
than ten percentage of the total MSW weight. Fly ash in 1 Waste Supply 2 Combustion Chamber 3 Boiler 4 the form of very fine particles remains suspended in the Scrubber 5 Filter 6 Draft fan 7 Stack with emissions exhaust gases. Enough oxygen is required for the complete monitoring 8 Bottom Ash Collection 9 Fly Ash combustion of the MSW also the MSW, given fuel if Collection required and gases produced should reach at enough temperature for enough time fr complete combustion process.

\section{E. Incomplete Combustion}

Large undesirable organic molecules can be created If the fuel does not burn completely and released at the output of incineration process plant of MSWM. Furans and dioxins substances are created after incomplete combustion of fuels containing chlorine. These organic molecules are in a range which is poisonous at varying levels. They get into the food chain once released into the environment and persist for longer times and accumulate in the fatty tissue of animals. Health issues such as developmental problems and immune system problems, certain cancers, liver disease are the consequences of exposure to furans and dioxins.

Incomplete combustion of any organic material such as treated timber or plastic containing chlorine produces Furans and dioxins. Very high temperatures is required and to be and maintained to prevent their release.

\section{III.INCINERATOR COMPONENTS AND OPERATION}

An incinerator is designed such as to achieve, [1]

1. Complete combustion of the waste

2. With the maximum output of heat energy to be obtained from the output gases to use it for electrical power production

3. As per the particular country norms minimal amounts of harmful gases and substances are released in atmosphere for that good cleaning of the exhaust gases is required,

Figures 1 [1] and 2 [2] shows the detail symbolic designs for Incinerator components and operation.

The construction and operation of an incinerator or incineration process plant are shown in five main stages:

A. Waste Storage and Preparation for Incineration:

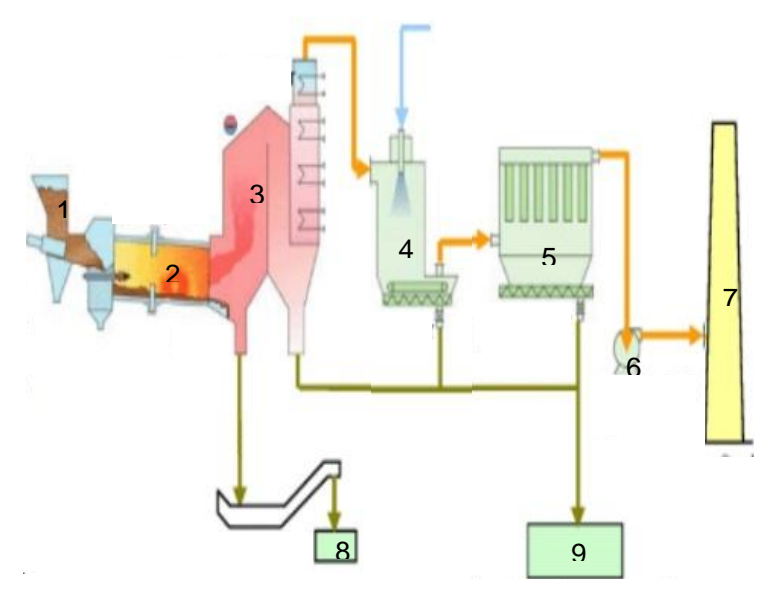

Figure 1- Block Diagram of an Incineration Plant

Sufficient waste has to be stored in the site of MSWM plant. Waste type always decides the type of storage. To minimize the release of odours in MSWM plant Solid wastes are usually stored under negative pressure. Any non-combustible materials such as metals other things should be removed. For faster handling and burning the MSW is first treated to reduce moisture content and then broken in to facility showing refuse storage pit, charging chute, furnace, grate, boiler, and turbine generator, with dry scrubber and bag house in the flue gas clean-up train[2].

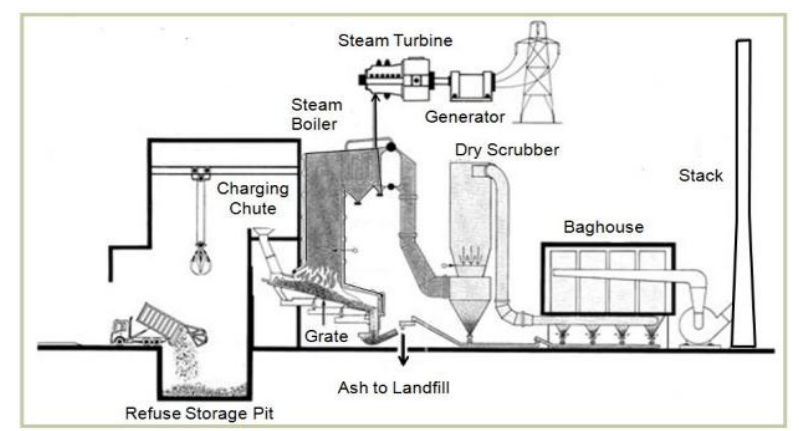

Figure 2 - Schematic diagram of an MSW incinerator

Pieces or pallets are made. Pallets or made particles are mixed thoroughly for uniform combustion process.

F. The Combustion Chamber.

This is the main part of the incineration process system where the combustion and thermal chemical reaction actually takes place. Dependent on the type of wastethere are different designs are available. [1]. A detailed summary of the main technology types is given in table 1 .

TABLE I TYPES OF COMBUSTION CHAMBER [1]

\begin{tabular}{|l|l|}
\hline \multicolumn{1}{|c|}{ Waste Type } & \multicolumn{1}{c|}{ Technology } \\
\hline Solid industrial or hazardous & Rotary Kiln \\
\hline Municipal Solid & Moving Grate \\
\hline Liquid or Gaseous & Static Hearth \\
\hline Homogenous e.g. sludge & Fluidized Bed \\
\hline
\end{tabular}

The common features are [1]:

1. An automatic movement and supply of the waste type in the chamber throughout the designed path is Managed.

2. Adjustable supply for forced air is so managed that that near to complete combustion takes place. Either low amount or high forced air will cause incomplete combustion process or low temperature for achieve complete combustion. Also the air is forced through storage are so that any dust or odours are brought in combustion area and destroyed before they mix in the atmosphere.

3. The chamber is designed such as to achieve thorough mix of the waste and air such that the gases are released with the air at outlet and complete combustion takes place. 4. Controllable supply of a secondary fuel like natural gas for the temperature to reach it's required limit for the incineration process. 
5. The chamber is designed such that the exhaust gases while moving to the boiler are able to maintain their temperature for required amount of time for power generation.

6. The chamber has an ash removal system and collection system also. Incinerator Bottom Ash is collected from the combustion chamber. The ash is handled in three steps.

1) It is cooled with water

2) Sorted in ash storage

3) Graded and used as a building aggregate.

G. Energy Extraction[1]

Through heat exchangers and boilers the hot exhaust or flue gases are passed and used to produce steam. This stem can be utilised in two ways.

1) It can be used to supply a local heat demand of industry

2) To drive turbines for production of electricity.

3) System is called a Combined Heat and Power (CHP) plant when Ideally both are done at the same time.

\section{H. Flue Gas Cleaning [1]}

For handling flue gases first, chemicals which produces acidsuch as $\mathrm{SO} 2$ and $\mathrm{HCl}$ as well as toxic heavy metals like mercury,cadmium, and lead are by process removed. Wet scrubbing is one of the method in which fine mist having an alkaline solution, which has lime, and active carbon is sprinkled or sprayed on the exhaust gases to get reacted with and capturing harm causing toxic substances. Selective catalytic reaction as well as ammonia injection in combustion gases is used to reduce NOx level.

High level of toxic substances are contained in residues and fly ash. So residues and fly ash are usually deposited in special landfill sites made for such toxic substances containing residues and fly ash.

I. Flue Gas Monitoring [3]

At Final stage a thorough exhaust analysis is done to so as to ensure that total number of harm causing substances which are released from the outlet of the incineration plant in atmosphere are below the particular country norms permitted levels. The monitored substances will depend on the type of waste but include $\mathrm{SO} 2, \mathrm{HCl}$, NOx furans, dioxins and heavy metals, and total organic carbon (TOC). The last figure measures amount of carbon which is not completely combusted.

\section{IV.TYPE OF SOLID WASTES AND POSSIBILITIES OF ELECTRICAL POWER PRODUCTION BY INCINERATION PROCESS}

If a list of solid waste is available which is produced in various states of a country as well as a list is available which shows the heat output of the particular MSW component then a rough estimate of possibility of electrical power production can be obtained for each of the states and their cities or metro cities.

Table 2.[3] Shows the municipal solid waste generation in various states of India where the incineration process is possible to produce the electrical power.

Source: Municipal solid waste generation rates in different states in India [3].
TABLE2. MUNICIPAL SOLID WASTE GENERATION IN VARIOUS STATES OF INDIA

\begin{tabular}{|c|c|c|c|}
\hline Sr. No & State & $\begin{array}{l}\text { No. of } \\
\text { cities }\end{array}$ & $\begin{array}{l}\text { MSW } \\
\text { (t/day) }\end{array}$ \\
\hline 1. & $\begin{array}{l}\text { Andhra } \\
\text { Pradesh }\end{array}$ & 32 & 3943 \\
\hline 2. & Assam & 4 & 196 \\
\hline 3. & Bihar & 17 & 1479 \\
\hline 4. & Gujarat & 21 & 3805 \\
\hline 5. & Haryana & 12 & 623 \\
\hline 6. & $\begin{array}{l}\text { Himachal } \\
\text { Pradesh }\end{array}$ & 1 & 35 \\
\hline 7. & Karnataka & 21 & 3118 \\
\hline 8. & Kerala & 146 & 1220 \\
\hline 9. & M.P. & 23 & 2286 \\
\hline 10. & Maharashtra & 27 & 8589 \\
\hline 11. & Manipur & 1 & 40 \\
\hline 12. & Meghalaya & 1 & 35 \\
\hline 13. & Mizoram & 1 & 46 \\
\hline 14. & Orissa & 7 & 646 \\
\hline 15. & Punjab & 10 & 1001 \\
\hline 16. & Rajasthan & 14 & 1768 \\
\hline 17. & Tamil Nadu & 25 & 5021 \\
\hline 18. & Tripura & 1 & 33 \\
\hline 19. & U.P. & 41 & 5515 \\
\hline 20. & $\begin{array}{l}\text { West } \\
\text { Bengal }\end{array}$ & 23 & 4475 \\
\hline 21. & Chandigarh & 1 & 200 \\
\hline 22. & Delhi & 1 & 4000 \\
\hline 23. & Pondicherry & 1 & 60 \\
\hline
\end{tabular}

TABLE 3 (PART-1)

PERCENTAGE PHYSICAL CHARACTERISTICS OF MSW IN VARIOUS CITIES [3]

\begin{tabular}{|c|c|c|c|c|}
\hline $\begin{array}{l}\text { Sr. } \\
\text { NO. }\end{array}$ & $\begin{array}{l}\text { Name of } \\
\text { metro city }\end{array}$ & Paper & Textile & Lather \\
\hline 1. & Ahmedabad & 6.0 & 1.0 & - \\
\hline 2. & Bangalore & 8.0 & 5.0 & - \\
\hline 3. & Bhopal & 10.0 & 5.0 & 2.0 \\
\hline 4. & Mumbai & 10.0 & 3.6 & 0.2 \\
\hline 5. & Calcutta & 10.0 & 3.0 & 1.0 \\
\hline 6. & Coimbatore & 5.0 & 9.0 & - \\
\hline 7. & Delhi & 6.6 & 4.0 & 0.6 \\
\hline 8. & Hyderabad & 7.0 & 1.7 & - \\
\hline 9. & Indore & 5.0 & 2.0 & - \\
\hline 10. & Jaipur & 6.0 & 2.0 & - \\
\hline 11. & Kanpur & 5.0 & 1.0 & 5.0 \\
\hline 12. & Kochi & 4.9 & - & - \\
\hline 13. & Lucknow & 4.0 & 2.0 & - \\
\hline 14. & Ludhiana & 3.0 & 5.0 & - \\
\hline 15. & Madras & 10.0 & 5.0 & 5.0 \\
\hline 16. & Madurai & 5.0 & 1.0 & - \\
\hline 17. & Nagpur & 4.5 & 7.0 & 1.9 \\
\hline 18. & Patna & 4.0 & 5.0 & 2.0 \\
\hline 19. & Pune & 5.0 & - & - \\
\hline 20. & Surat & 4.0 & 5.0 & - \\
\hline 21. & Vadodara & 4.0 & - & - \\
\hline 22. & Varanasi & 3.0 & 4.0 & - \\
\hline 23. & Visakhapatna & 3.0 & 2.0 & - \\
\hline
\end{tabular}


Table 3 shows the physical characteristics of Solid waste available at a particular place [3].

Table 3 is divided in to three parts; first part shows the percentage of paper, textile and lather which are combustible. Second part shows the percentage of plastic, metal and glass where plastic is combustible in nature, and third part of table 3 shows the ash and compostable matter as percentage components of MSW available at various places.

Table 4 shows he heating values of MSW available in cities like textile, chart board, soft paper, plastic foil, hard foil, PET bottles, wood and Styrofoam [4].

TABLE 4 HEATING VALUES OF MSW AVAILABLE IN CITIES.

\begin{tabular}{|c|c|c|}
\hline $\begin{array}{c}\text { Sr. } \\
\text { NO. }\end{array}$ & $\begin{array}{c}\text { Name of } \\
\text { MSW portion }\end{array}$ & $\begin{array}{c}\text { Heating value } \\
(\mathrm{MJ} / \mathrm{KG})\end{array}$ \\
\hline 1. & Textile & 16.65 \\
\hline 2. & Chart board & 17.49 \\
\hline 3. & Soft Paper & 10.1 \\
\hline 4. & Plastic Foil & 40.14 \\
\hline 5. & Hard Foil & 40.12 \\
\hline 6. & PET bottles & 21.51 \\
\hline 7. & Wood & 16.32 \\
\hline 8. & Styrofoam & 27.95 \\
\hline
\end{tabular}

TABLE 3 (PART-2)

PERCENTAGE PHYSICAL CHARACTERISTICS OF MSW IN VARIOUS CITIES [3]

\begin{tabular}{|c|c|c|c|c|}
\hline $\begin{array}{l}\text { Sr. } \\
\text { NO. }\end{array}$ & $\begin{array}{l}\text { Name of metro } \\
\text { city }\end{array}$ & Plastic & Metals & Glass \\
\hline 1. & Ahmedabad & 3.0 & - & - \\
\hline 2. & Bangalore & 6.0 & 3.0 & 6.0 \\
\hline 3. & Bhopal & 2.0 & - & 1.0 \\
\hline 4. & Mumbai & 2.0 & - & 0.2 \\
\hline 5. & Calcutta & 8.0 & - & 3.0 \\
\hline 6. & Coimbatore & 1.0 & - & - \\
\hline 7. & Delhi & 1.5 & 2.5 & 1.2 \\
\hline 8. & Hyderabad & 1.3 & - & - \\
\hline 9. & Indore & 1.0 & - & - \\
\hline 10. & Jaipur & 1.0 & - & 2.0 \\
\hline 11. & Kanpur & 1.5 & - & - \\
\hline 12. & Kochi & 1.1 & - & - \\
\hline 13. & Lucknow & 4.0 & 1.0 & - \\
\hline 14. & Ludhiana & 3.0 & - & - \\
\hline 15. & Madras & 3.0 & - & - \\
\hline 16. & Madurai & $3 . .0$ & - & - \\
\hline 17. & Nagpur & 1.25 & 0.35 & 1.2 \\
\hline 18. & Patna & 6.0 & 1.0 & 2.0 \\
\hline 19. & Pune & 5.0 & - & 10.0 \\
\hline 20. & Surat & 3.0 & - & 3.0 \\
\hline 21. & Vadodara & 7.0 & - & - \\
\hline 22. & Varanasi & 10.0 & - & - \\
\hline 23. & Visakhapatnam & 5.0 & - & 5.0 \\
\hline
\end{tabular}

TABLE 3 (PART-3)

PERCENTAGE PHYSICAL CHARACTERISTICS OF MSW IN VARIOUS CITIES [3]

\begin{tabular}{|c|c|c|c|}
\hline $\begin{array}{l}\text { Sr. } \\
\text { NO. }\end{array}$ & $\begin{array}{l}\text { Name of metro } \\
\text { city }\end{array}$ & $\begin{array}{l}\text { Ash and } \\
\text { fine earth } \\
\text { matter }\end{array}$ & $\begin{array}{l}\text { Compostable } \\
\text { matter }\end{array}$ \\
\hline 1. & Ahmedabad & 50.0 & 40.00 \\
\hline 2. & Bangalore & 27.0 & 45.0 \\
\hline 3. & Bhopal & 35.0 & 45.0 \\
\hline 4. & Mumbai & 44.0 & 40.0 \\
\hline 5. & Calcutta & 35.0 & 40.00 \\
\hline 6. & Coimbatore & 50.0 & 35.0 \\
\hline 7. & Delhi & 51.5 & 37.78 \\
\hline 8. & Hyderabad & 50.00 & 40.00 \\
\hline 9. & Indore & 49.00 & 43.00 \\
\hline 10. & Jaipur & 47.00 & 42.00 \\
\hline 11. & Kanpur & 52.5 & 40.00 \\
\hline 12. & Kochi & 36.0 & 58.00 \\
\hline 13. & Lucknow & 49.00 & 40.00 \\
\hline 14. & Ludhiana & 30.00 & 40.00 \\
\hline 15. & Madras & 33.0 & 44.00 \\
\hline 16. & Madurai & 46.0 & 45.0 \\
\hline 17. & Nagpur & 53.4 & 30.40 \\
\hline 18. & Patna & 35.0 & 45.00 \\
\hline 19. & Pune & 15.0 & 55.00 \\
\hline 20. & Surat & 45.0 & 40.0 \\
\hline 21. & Vadodara & 49.0 & 40.00 \\
\hline 22. & Varanasi & 35.00 & 48.00 \\
\hline 23. & Visakhapatnam & 50.00 & 35.00 \\
\hline
\end{tabular}

\section{CONCLUSION}

An incineration process is very useful to produce a large amount electrical power. Table 2[3], table 3[3] (Part1, part 2 and part 3) and table 4[4] shows the type of solid wastes available and the heating value of the same. So in most of the big cities there is a possibility of producing high amount of electric power by MSW incineration process and at the same time solid waste is converted to energy rather than dumping at land filling and producing environ hazards effects.

Following are some of the advantages [1] and disadvantages [1] of incineration process to produce electrical power.

A. Advantages:

1. This method is practical enough for disposition of wastes such as contaminated material and unwanted chemicals which cannot be taken to non-spatial normal landfill. In unavailability of incineration process such material has to be exported.

2. It significantly reduces (the Ash is having weight around $10 \%$ of the main MSW component) the material quantity that has to be taken to landfill and associated pollution risks.

3. Produces electrical energy from waste, reduces fossil fuel consumption and resulting greenhouse gas (GHG) emission.

4. The GHG emissions, energy usage and costs, can be lower than those in the transport, collection and processing of MSW involved in recycling. 
5. Building incinerators near to urban areas causes reduction of the cost of waste transport.

B. Disadvantages:

1. There is a chance of release of harm causing degrees of gases if incineration plant is incorrectly operated.

Even when the operation is done properly small amounts of pollutants and fine particles are released. New mature technologies are immerging so that emission levels have also reduced.

2. Production of Large amount of fly ash (approximately $4 \%$ of original waste weight) is observed in Incineration of MSW. So the fly ash has to treat so as to capture them and dumped in landfill.

3. Incineration process reduces chances the recycle incentive. The energy is much less than unsegregated waste content in the MSW waste than the case with all recyclable components removed. So that only some materials can be recycled. Following tabulation gives the details of recyclable quantities in MSW [5].

TABLE 5 TOTAL RECYCLABLE QUANTITIES OUT OF MSW AVAILABLE IN CITIES.

\begin{tabular}{|l|l|l|}
\hline $\begin{array}{l}\text { Total } \\
\text { population } \\
\text { (in millions) }\end{array}$ & $\begin{array}{l}\text { Average per } \\
\text { capita waste } \\
\text { generation } \\
\text { (Kg/capita/day) }\end{array}$ & $\begin{array}{l}\text { Total } \\
\text { recyclables } \\
(\%)\end{array}$ \\
\hline$<0.1$ & $0.17-0.54$ & $13.68-36.64$ \\
\hline $0.1-0.5$ & $0.22-0.59$ & $13.68-36.64$ \\
\hline $0.5-1.0$ & - & $11-24$ \\
\hline $1.0-2.0$ & $0.19-0.53$ & $9-25$ \\
\hline$>2.0$ & $0.22-0.62$ & $11-22$ \\
\hline
\end{tabular}

Source: Waste generation and its characteristics in Indian cities [5]

4. Long term contracts and large initial capital cost are required for viability of Incineration plants. Deployment of future more efficient waste treatment technology may be hampered by this.

\section{REFERENCES}

[1] Engineering1.pbworks.com, 'engineering1 [licensed for noncommercial use only] / Incineration', 2015. [Online]. Available: http://engineering1.pbworks.com/w/page/32234029/Incineration. [Accessed: 1- Oct- 2015].

[2] Enviro power renewable Inc., 'A Comparative Assessment of Commercial Technologies for Conversion of Solid Waste to Energy', 2013.

[3] M. Sharholy, K. Ahmad, G. Mahmood and R. Trivedi, 'Municipal solid waste management in Indian cities - A review', Waste Management, vol. 28, no. 2, pp. 459-467, 2008.

[4] Filip Kokalj and Niko Samec (2013). Combustion of Municipal Solid Waste for Power Production, Advances in Internal Combustion Engines and Fuel Technologies, Dr. Hoon Kiat $\mathrm{Ng}$ (Ed.), ISBN: 978-953-51-1048-4, InTech, DOI: 10.5772/55497. Available from: http://www.intechopen.com/books/advances-ininternal-combustion-engines-and-fuel-technologies/combustion-ofmunicipal-solid-waste-for-power-production

[5] R. Dube, V. Nandan and S. Dua, 'Waste incineration for urban India: valuable contribution to sustainable MSWM or inappropriate high-tech solution affecting livelihoods and public health?', International Journal of Environmental Technology and Management, vol. 17, no. 234, p. 199, 2014. 